\title{
抗菌成分の徐放性に及ぼすテトラエトキシシランの 加水分解物による抗菌剂表面被覆の影響
}

\author{
（1996 年 2 月 5 日受理）
}

\author{
冨岡敏一*・冨田勝己・西野敦
}

\begin{abstract}
シリカゲル担体にチオスルファト銀錯体を担持させ，テトラエトキシシラン加水分解物によりその表 面を被覆した抗菌剤を調製した．表面被覆処理により，抗菌成分の徐放性向上が認められた．抗菌成分 は, 抗菌剤含有樹脂中で周囲樹脂中に浸出することを, 表面分析により確認した. さらに, 樹脂表面が 水分と接触することで水分中に浸出する．抗菌剂表面を被覆するTEOS 処理量の増加とともに，抗菌 成分漫出速度が低下することを確認した。これらのことから，抗菌剤表面をTEOS 加水分解物で被覆 することで抗菌成分の徐放性向上に対する効果が認められた.
\end{abstract}

\section{1 緒言}

日常生活で用いられる多くの製品に, 抗菌処理が道入されつつ ある.その抗菌成分として, 銀が安全性やリサイクル・環境など の面から注目されている1)。従来から用いられてきた有機系の抗 菌剤に対し，無機物の銀を抗菌成分とすることにより，常温で蒸 気圧が低く，抗菌成分が揮散し難いので，製品在庫時も含めた抗 菌効果の持続性が期待できる. 特に, チオスルファト銀錯体を用 いることで，耐熱性があり，塩化物イオン共存下においても沈殿 を生じず，微生物の存在する環境への漫出が迅速であることを報

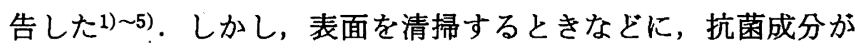
抗菌製品使用環境中の水に浸出することから，抗菌性能の持続性 に課題がある. 一方，抗菌成分である銀錯体を担体に担持した後 に，表面をテトラエトキシシラン(以下 TEOS と略称）の加水分 解物で被覆することにより，抗菌剤の耐熱性が向上することを報 告した ${ }^{6)}$. 本論文では，このTEOS 加水分解物による被覆が抗 菌成分の徐放性に及ぼす影響について報告する.

\section{2 実験}

\section{1 抗菌剤の調製}

抗菌剂の調製は以下の手順で行った。まず，酢酸銀 $\left(\mathrm{CH}_{3}\right.$ COOAg Mw=167） $2.64 \mathrm{mmol}$ を約 $60^{\circ} \mathrm{C}$ 純水 $60 \mathrm{ml}$ に溶解さ せ，飽和溶液を調製した。これに亜硫酸カリウム $7.93 \mathrm{mmol}$ ，お よびチオ硫酸カリウム $15.86 \mathrm{mmol}$ を順次溶解させ, 銀の錯体を 得た。この銀の錯体を含む溶液に，担体としてシリカゲル(JIS B 型) $5.0 \mathrm{~g}$ を混合し担持させ，乾燥して吸着体を得た．その表 面処理としてTEOS $1.0 \mathrm{~g}$ とエタノール $1.0 \mathrm{~g}$ の混合液中に上記 吸着体 $1.0 \mathrm{~g}$ を分散させ, $0.20 \mathrm{~g}$ の純水を滴下し, 約 $60^{\circ} \mathrm{C}$ 温 湯浴上で加水分解物を析出させる，いわゆるソルーゲル法によ

松下電器産業株式会社生活環境研究所, 570 守口市八雲 中町 3-1-1
り,シリカのコーティング被膜を形成させて抗菌㓮(被覆率 $=0.288$ )を得た．被覆率(表面処理量) を隇しる抗菌剤の調製 は，吸着体量および TEOS とエタノールの混合液量を一定とし， TEOS 量を減し，滴下純水量は TEOS 量に比例させることによ り行った.

シリカゲルは富士シシリシア化学(㹬製, その他はいずれも関東化 学(侏製特級試薬を用いた。

\section{2 抗菌郕分散樹脂の調製}

日本石油化学(㑣製透明ポリブロピレン樹脂(商品名 J-152MA) 100 重量部に, 2.1により調製された試料 1 重量部を均一混合分 散さ过，住友重機械工業侏製射出成形機 MINIMAT 14/7B 型を 用い, $2 \mathrm{~cm} \times 3 \mathrm{~cm} \times 2 \mathrm{mmt}$ 試料片金型を用い $220^{\circ} \mathrm{C}$ で成形し, 試料片を得た.

\section{3 特性 X 線による樹脂表面の元素分析}

試料の表面に金蒸着を施し，島津製作所(制製電子線マイクロア ナライザー(EPMA-C1 型) を用い, 表面走査型電子顕徽鏡像, 構成元素の特性 $\mathrm{X}$ 線の二次元分布像 (X 線像と略) を観察した.

抗菌剂の抗菌有効成分が, $\mathrm{K}_{10}\left[\mathrm{Ag}_{6}\left(\mathrm{~S}_{2} \mathrm{O}_{3}\right)_{8}\right]$ で示されるチオ スルファト銀錯体であることを報告した ${ }^{5)}$. 抗菌片の構成元素 は，その担体抢よび被覆材として用いられる二酸化ケイ素と，抗 菌成分の銀, 硫黄, カリウムであるが, それらの中で存在比率が 高く，したがって検出感度の良かったケイ素抏よび硫黄を観察元 素として用いた．また，その二次元分布像作眓には，島津製作所 (㮫製 EPMA 用高速マッピング装置抢よびソフト H II， H III （Ver. 3.2）を用いた.

\section{4 抗菌剤分散樹脂からの抗菌成分浸出速度の測定}

2.2により調製された各被覆率 (=[TEOS 加水分解物重量/吸 着体重量] -1）の試料各 5 枚を, ボリエチレン製密封容器中に 入れ, $30 \mathrm{ml}$ の純水中に漫漬し, 微生物試験で用いる大腸菌など の増殖最適温度である $37{ }^{\circ} \mathrm{C}$ 雾囲気下で，実験終了まで 6 日間 ふりまぜた. 所定時間経過後, この液から $0.5 \mathrm{ml}$ 採取し, 日立 
製作所製 Z-1500 型原子吸光分析装置を用いて溶存銀量を測定し た. 溶存銀量の测定値を，抗菌成分の漫出量の銀換算値とした.

各测定時間での測定值銀量と，調製初期の全試料樹脂中に含まれ ていた銀量の割合を求め，各测定時間ごとにそれぞれの浸出量の 増加分から，その間での浸出比率を漫出速度として求めた.

\section{3 結果および考察}

\section{1 抗菌凧分散樹脂表面の抗菌成分分布}

抗菌荗分散樹脂表面の走査型電子顕微鏡写真を図 1a に示す. 分散させた抗菌風の平均粒径が約 $5 \mu \mathrm{m}$ で，それそれが凝集せず 均一分散されていることが観察された.

つぎに，ケイ素のX 線像を図 1bに示す. 図 1a で観察された 粒子位㯰に，図1bではケイ素の像が認められた，抗菌剤は，シ リカゲルを担体として利用し，加その表面が TEOS 加水分解 物であるシリカで被覆されていることから，その表面の構成元素 にはケイ素を含む. 図1aでの粒子の䍋宗結果と、ケイ素を含む 抗菌風の分布が一致することから，図 1a の粒子が抗菌剤粒子で あることが確諗された.

硫黄のX線像を図 1cに示す，この図には，図 1a および図 1b で観察された位置以外に，図1a および図1bで確認されていな い別の場所に同程度の大きさの像が数力所認められる. しかし， これらの像は図 1a で観察されていないことから，樹脂表面の山 凸を伴う抗菌剤粒子ではなく，表面より少し深部に存在する抗菌 剂粒子より，抗菌剤成分としてチオスルファト銀錯体が周囲樹脂 中に浸出したものを観察したと考えられる.

樹脂の成形時には $200^{\circ} \mathrm{C}$ 上小温度で，溶融樹脂中に抗菌剂を 分散させるため, 抗菌成分である銀錯体が抗菌剤より樹脂中に拡 散したと考えられる.

これらのことから，樹脂表面の抗菌成分は，樹脂表面に存在す る抗菌剤中に含まれるものと，抗菌剤から周囲樹脂中に拡散し樹 脂表面に浸出したむのがあり，双方で抗菌作用に関与するすのと 思われる. いいかえると, 成形直後の樹脂表面に関して，樹脂表 面より抗菌剤粒子径程度の澡さまでに分布する抗菌成分が，抗菌 作用に関与することを示唆する.

\section{2 抗菌成分の漫出}

抗菌凧の耐熱性を向上させる効果を有する TEOS 加水分解物 の被覆処理か，抗菌成分である銀錯体中の銀の抗菌剤から浸出す る速度に及ぼす影響についてつぎに述べる。

TEOS 無処理(被覆率＝0）から2.1Kよる表面処理(被覆率 =0.288） までの各被覆率の抗菌㓩，それぞれについて2.2に従い 分散樹脂を調製し，純水中に6 日間漫漬した. それそれの試料 樹脂表面から銀の単位時間当たりの浸出量について, 2.4の方法 で測定した.

被覆率が抗菌成分である銀浸出速度に及ぼす影響について，そ の測定結果を図 2 に示す.

その結果，表面処理を施した各抗菌剤の試料樹脂において，浸 漬後約 0.5 時間で銀浸出速度に極大が観察された.

一方，表面処理を施さない抗菌剂分散樹脂の銀漫出速度につい て，極大は漫溃直後と考えられ，TEOS 加水分解物による表面 被覆処理により, 抗菌成分浸出速度の最大時期を遅延させる徐放 奻果が観察された.

大腸菌をはじめとする代表的な細菌類は，約 20 分で分裂を繰
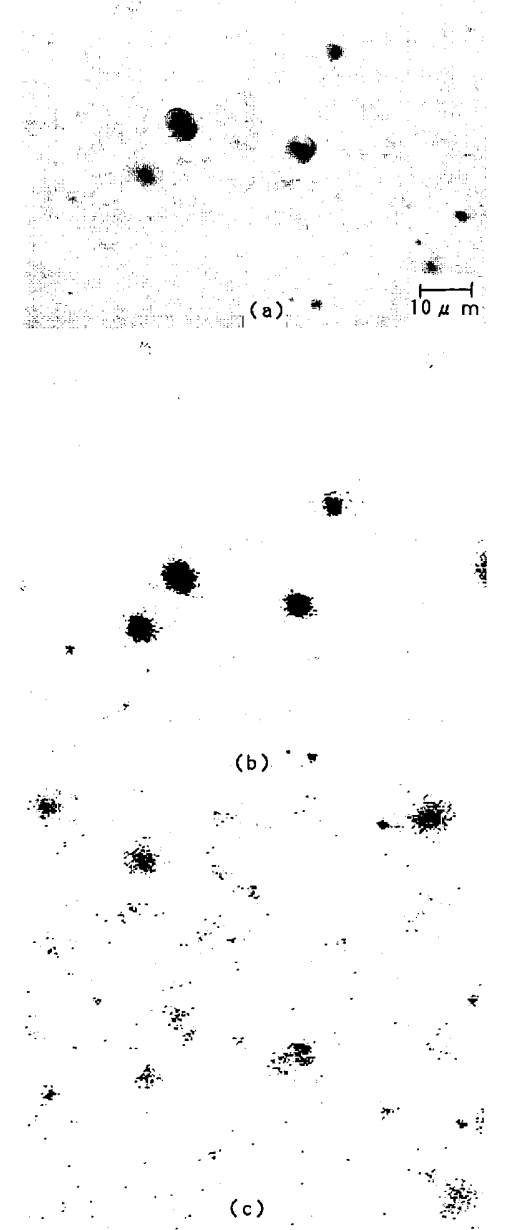

Fig. 1 (a) SEM observation of the surface of the resin with anti-microbial materials.

(b) Observation of $\mathrm{Si}$ image on the surface of the resin by EPMA

(c) Observation of $\mathrm{S}$ image on the surface of the resin by EPMA

り返し増殖する. 一方，抗菌剤分散樹脂の実用状況は，数分間の 湿潤状態を繰り返す使用条件が最も多い，時々水滴が数十分間滴 下放置される状況があり，その際に付着細菌は，樹脂表面の栄養 源を得て増殖が活発になり，抗菌剂による抗菌性能の発揮が望ま れる.ほとんどの使用条件下にあっては，分裂を綝り返す増殖前 に乾燥状態になり，細菌は増殖し難い。

そのため，抗菌郕としては数分間の湿潤状態では，抗菌剤の漫 


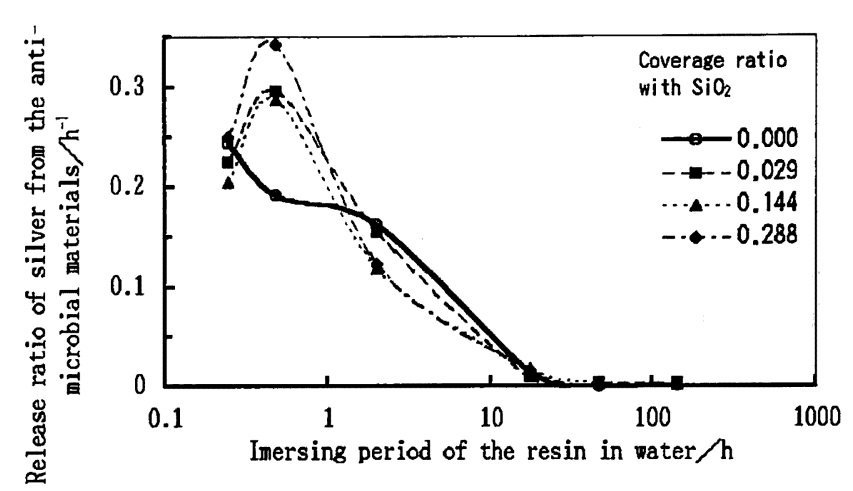

Fig. 2 Release ratio of the effective component from the anti-microbial materials.

出は少なく，分裂時間を超える数十分の湿潤状態で抗菌成分が多 く浸出する浸出制御が望まれる.

表面処理を施すことで, 抗菌成分漫出速度の最大時期を遅延さ せるため, 短時間の湿潤状態では抗菌成分の漫出が少なく, 浸出 しても乾燥し，再吸着されるため抗菌成分の失われる割合が少な くなる. 一方数十分を越える湿潤状態で抗菌成分が浸出し, 細菌 の増殖を抑止する.

また，大腸菌の場合，水中の抗菌剤濃度が約 $1 \mathrm{ppm}$ で実用的 な抗菌性能を発揮する.

一方, 樹脂表面に付着できる水分量を $1 \mathrm{ml} / \mathrm{cm}^{2}$, 抗菌性能に 関与する抗菌樹脂深さを $5 \mu \mathrm{m}$, 抗菌剤添加量を $1 \%$ とし, 抗菌 樹脂中に含まれる抗菌剤 $(5 \mathrm{ppm})$ が，抗菌性能を発揮するため の抗菌成分浸出速度 (浸出比率) を計算すると, 約 $0.2 / \mathrm{h}$ となる. すなわち， $0.2 / \mathrm{h}$ の抗菌成分漫出速度を長時間保つことのできる 表面処理が，抗菌剤の耐久性能を考慮した最適表面処理条件とい える.

上記試算より，TEOS 表面処理により十分な初期抗菌性能が 期待でき，それを確認した．またその表面処理を施すことで，湿 潤状態を繰り返しても抗菌成分の漫出を抑止できる.

このことから, 抗菌風分散樹脂を水中浸漬した際, 表面処理に より抗菌成分漫出速度を制御することができていることを示唆す る.

また, 2 時間後より銀漫出速度は被覆率の増加に伴い减少し， 数時間にわたり被覆率の増加に伴う銀漫出速度の遅延が認められ た.

実験終了までの 6 日間の総浸出銀量は, $2 \mathrm{~mm}$ 厚みの樹脂表面 から約 $5 \mu \mathrm{m}$ 内部までに存在する抗菌剤中に含まれる銀量にほほ 相当した.

実験に供した抗菌凧の平均粒径が約 $5 \mu \mathrm{m}$ であることから, 樹
脂表面約 $5 \mu \mathrm{m}$ 深部までに存在する抗菌剤からその有効成分であ る銀錯体が浸出したものと推定される.さらに，実験終了時には 表面に存在する抗菌剤から銀のほとんどが漫出したと考えられ る.このことは, 樹脂表面より抗菌剤粒子径程度の深さまでに分 布する抗菌成分が抗菌作用に関与するとした3.19X 線像観察結 果とも一致する.

TEOS 加水分解物による表面処理は, 担体シリカゲルと化学 的に結合しているが，銀錯体とは担持効果による物理的な吸着の みで, 熱・溶媒などの影響で被覆層あるいはその間隙を経由して 漫出可能な層として存在すると考えられる.

これらのことから，TEOS 加水分解物による被覆は抗菌成分 の徐放層としての効果のあることが示唆された.

\section{4 結論}

抗菌成分であるチオスルファト銀錯体の徐放性に及ほすす TEOS 加水分解物による抗菌剂表面被覆の影響について, 以下 のことが明らかになった.

1. 抗菌剤含有樹脂の表面解析により，樹脂表面より少し深部 に存在する抗菌剂粒子より抗菌剤成分としてチオスルファト銀錯 体が周囲樹脂中に浸出したものが観察され，抗菌成分が抗菌剤よ り樹脂中に拡散したことを示唆する.

2. TEOS 加水分解物による表面被覆処理により, 抗菌剂分散 樹脂を办中漫漬した際, 抗菌成分である銀錯体の漫出速度の最大 時期を遅延させる徐放効果が観察された.

3. 被覆率の増加に伴い, 抗菌成分浸出速度を减少させる浸出 量遅延効果が認められた.

4. 抗菌成分漫出総量は, 試料樹脂表層（約 $5 \mu \mathrm{m}$ 深さ）に存 在する抗菌剤中に含まれる抗菌成分とほぼ同量であることを確認 した.

本研究を遂行するに当たりこ指導, こ助言を戴いた大阪府立大 学工学部機能物質科学科南 努教授に深く感謝致します.

1）冨岡敏一, 冨田勝己, 岡 弘章, 宮地寿明, 西野 敦, 防菌防徽, 21, 543(1993).

2) 富岡敏一, 富田勝已, 岡弘章, 西野敦, 日化, 1995, 848.

3）富岡敏一, 冨田勝己, 岡 弘章, 西野 敦, 表面技術誌, 47, 42(1996).

4) 富岡敏一, 富田勝己, 岡弘章, 西野敦, 日化, 1996, 200.

5）畐岡敏一, 冨田勝己, 西野敦, 楠木正巳, 日化, $1996,411$.

6）富岡敏一, 冨田勝己，岡 弘章，西野 敦，表面技術誌， 46, 572(1995). 


\section{Release Control of Anti-microbial Materials Coated with Hydrolyzed Tetraethoxysilane}

\section{Toshikazu TomioKA*, Katsumi TomiTA and Atsushi NISHINO}

Human Environment Research Laboratory, Matsushita Electric Industrial Co.; 3-1-1 Yakumo-nakamachi, Moriguchi-shi 570 Japan

Anti-microbial materials were synthesized with thiosulfatosilver complex on silica gel. Release ratio of the effective component from the materials was improved with coating on the surface with hydrolyzed tetraethoxysilane (TEOS). It was observed by EPMA (Electron probe micro analyzer) that the effective component from the materials was leached out around the materials through the resin. It was also confirmed that the coating was effective for the improvement of release ratio with increasing amount of TEOS used. 